\title{
Preserving the Perishing Endangered Natural Biodiversity of Socotra Island
}

\author{
Sanjay Saraf \\ NMC Specialty Hospital, Dubai, UAE \\ Email: drsaraf@hotmail.com
}

How to cite this paper: Saraf, S. (2021) Preserving the Perishing Endangered Natural Biodiversity of Socotra Island. Open Journal of Ecology, 11, 148-162. https://doi.org/10.4236/oje.2021.112013

Received: January 6, 2021

Accepted: February 16, 2021

Published: February 19, 2021

Copyright $\odot 2021$ by author(s) and Scientific Research Publishing Inc. This work is licensed under the Creative Commons Attribution International License (CC BY 4.0).

http://creativecommons.org/licenses/by/4.0/

\begin{abstract}
Socotra Island is one of the most biodiversity rich and distinct islands in the world and hosts one of the oldest ecosystems on Earth. Located in the Indian Ocean, the Socotra ecosystem is uniquely characterized by incredible rare species of endemic flora, fauna and marine biodiversity, a third of which are found nowhere else on the Earth. The objective of this paper is to review the current status of conservation efforts and propose recommendations for the preservation of this island's fragile ecosystem in order to conserve its unique biodiversity and endemism, which will otherwise perish in oblivion forever.
\end{abstract}

\section{Keywords}

Socotra Island, Dragon Tree Island, Biodiversity, Endemism

\section{Introduction}

Socotra is often dubbed as the "Galapagos of the Indian Ocean" because of its exceptionally high level of biodiversity and endemism in its terrestrial and marine ecosystem. This distinct "living museum" of botanical and zoological treasure sits at the crossroads of three biogeographical regions and includes many unique endemic floras and faunas, including some varieties of plant which are more than 20 million years old (Figure 1). Socotra's biodiversity remained resilient for centuries, however, the last two decades have threatened the ecosystem for many reasons including habitat fragmentation, degradation of woodlands, adverse climatic changes, cyclones, cattle overgrazing, unsustainable development, increased tourism, negative influence on marine wildlife, limited conservation resources, as well as current political instability.

This paper further analyzes causative factors and their impact on biodiversity, current status of preservation and recommended steps to preserve this unique biodiversity. 


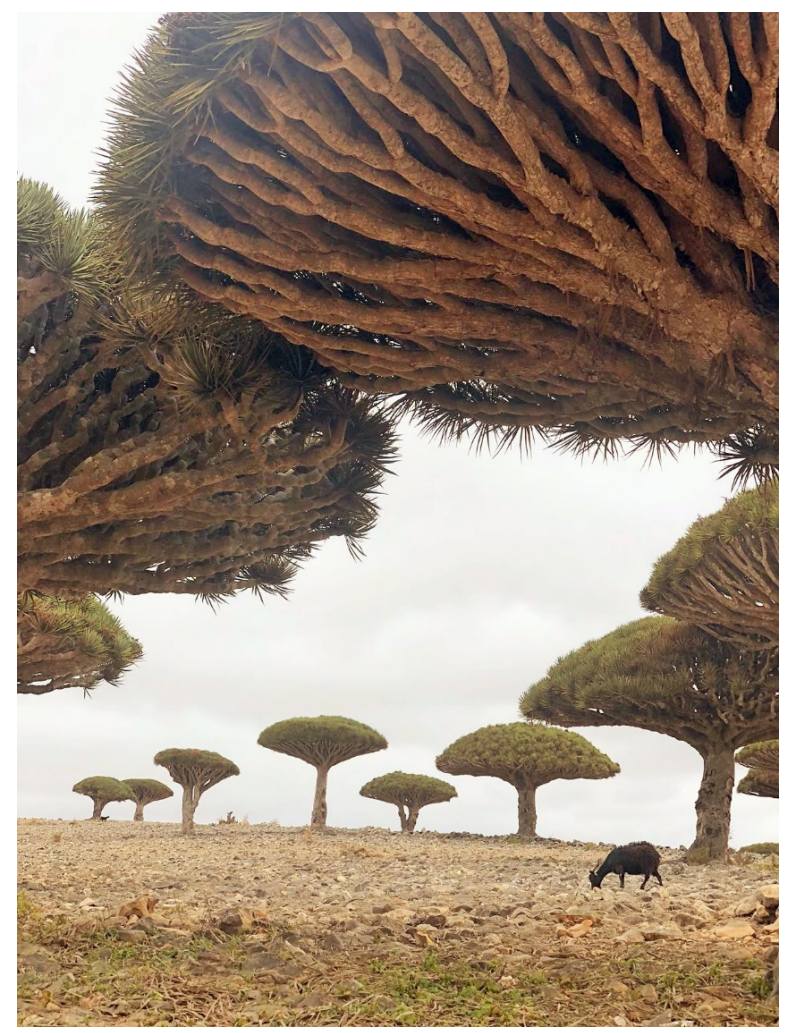

Figure 1. Dragon blood trees (Dracaena cinnabari): relics of the Cretaceous period (photo by author, Socotra 2018). These endangered species of trees are unique identity of Socotra Island and now occupies only $5 \%$ of habitat.

\section{Socotra Archipelago Geographical Location}

The Socotra Archipelago is part of the Republic of Yemen and is located in the northern part of the Indian Ocean off the Horn of Africa, about $380 \mathrm{~km}$ off the coast of Yemen and $250 \mathrm{~km}$ away from Somalia (Figure 2).

Biogeographically, Socotra is considered to be an extension of the Horn of Africa and is considered the oldest island of the Arabia. The Socotra archipelago is $250 \mathrm{~km}$ long and comprises a group of four islands and other small islets (Figure 3). Socotra forms the largest island of the eponymous archipelago of four islands (about 95\% of its landmass), followed by the three satellite islands which are collectively known as "the Brothers" Samha, Darsa, Abd Al Kuri, and other small rocky islets Jazirat, Sabuniya and Ka'l Fir'awn which are uninhabitable.

\section{Socotra Archipelago Vegetation}

The biological richness and diversity of insular faunas and floras of ecosystems are influenced by a combination of their geological history, geographical location, isolation and by the past and current climatic conditions [1] [2]. The study of such endemic species in insular habitats like Socotra deserves close attention as they not only help in unveiling the history of colonization, but also in speciation processes. 


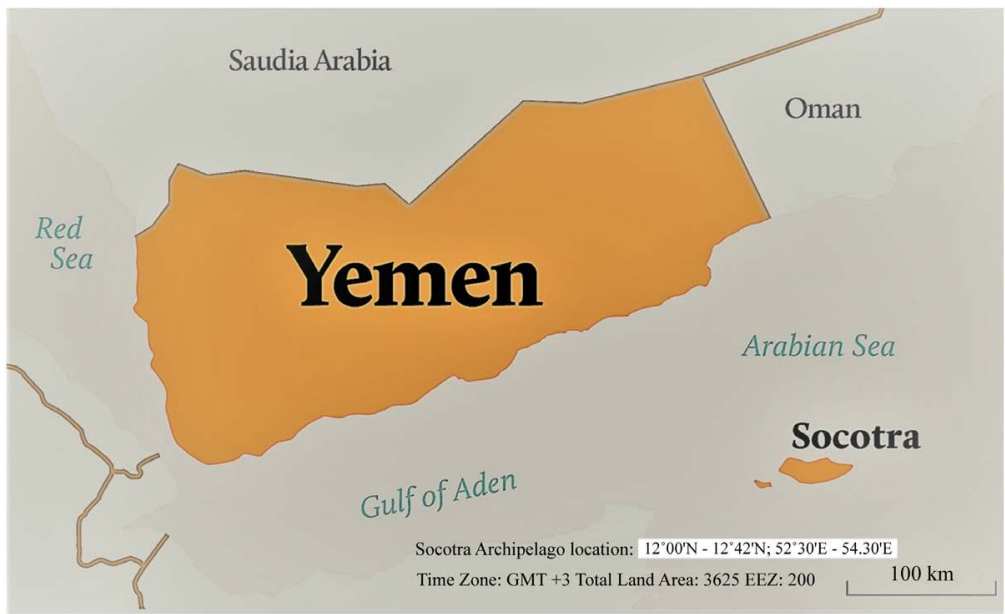

Figure 2. Geographical location of Socotra Archipelago “The Jewel of Arabia”. The Archipelago includes the main island Socotra (coordinates $12^{\circ} 30^{\prime} 36^{\prime \prime} \mathrm{N} 53^{\circ} 55^{\prime} 12^{\prime \prime} \mathrm{E}$ ); three satellite islands Abd Al Kuri, Samha, Darsa and small rocky outcrops.

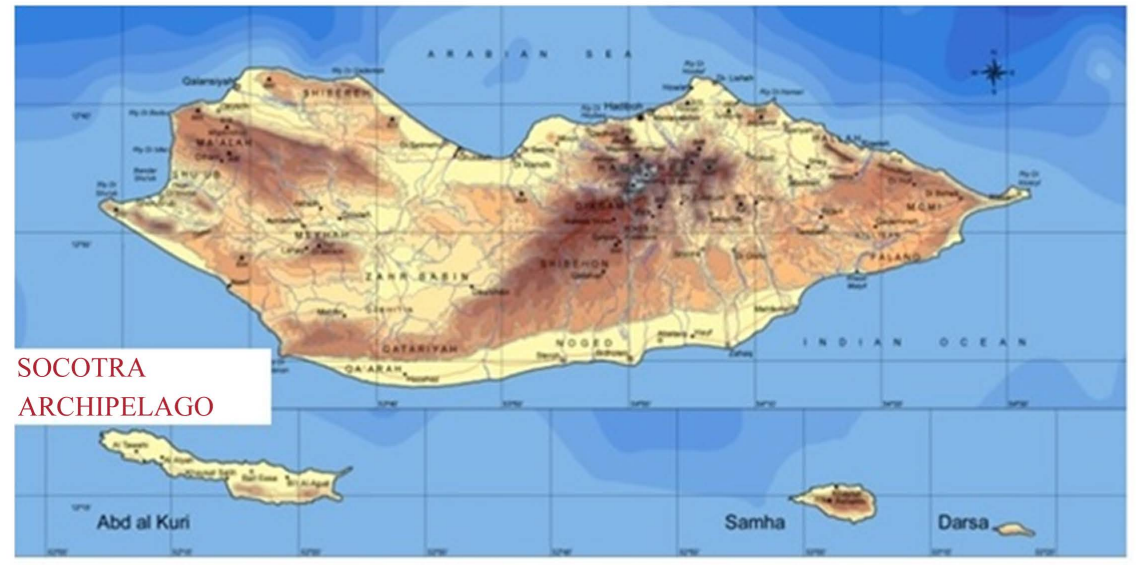

Socotra Archipelago "Galapagos of the Indian Ocean"

All four islands are situated east of Gulf of Aden on the so-called "Socotran Platform". The Socotra Island (Area $3625 \mathrm{~km}^{2}$ ) measures 132 kilometers ( 82 miles) in length and 49.7 kilom eters (30.9 miles) in width

Figure 3. Socotra archipelago is unparalleled for its unique flora and fauna and is considered a jewel of biodiversity and endemism.

The Archipelago of Socotra remained inaccessible for centuries due to its remote geographic location and extreme geopolitical conditions. This long period of geological isolation of the archipelago, variable climatic conditions with arid ecosystem and extensive coral reefs framework bordering the island contributed to Socotra's distinctly rich biodiversity. This unique characteristic of Socotra, with remarkable richness in endemic forms, attracted the attention of ecologists, scientists, researchers and evolutionary biologists for the study of the isolated biota's insularity since the second half of the 19th century [3].

Several attempts were made in past to classify the vegetation of Socotra Island physiognomically [4] [5] and phytosociologically [6]. However, owing to differ- 
ent approaches, the classifications and divisions of the vegetation are hardly comparable to each other. Kraal \& Pavliš (2006) [7] used satellite data combined with their own field observations and distinguished 19 land-cover classes including grasslands, shrub lands, woodlands, forests and mangroves. De Sanctis et al. (2013) [8] in his study recognized a geo-altitudinal gradient divided into four main vegetation belts: Semi-arid Haggier Mountain from 1000 to 1550 MASL (Meters Above Sea Level), arid limestone hills and plateau from 400 to 1000 MASL, a transition zone from 200 to 400 MASL and the arid coastal plain from sea level to $200 \mathrm{~m}$ of altitude. These host eight woody vegetation types, seven scrubland communities, six main herbaceous vegetation types and seven groups of halophytic vegetation concentrated in the arid coastal plain. The limestone plateau and the Haggier Mountains are the richest areas for endemic plant species. The coastal plains and low inland hills consist of open deciduous shrub land dominated by the endemic Croton socotranus and scattered trees of Euphorbia arbuscula, Dendrosicyos socotranus, and Ziziphus spina-christi. On the coastal foothills and the limestone plateau, the most widespread vegetation type is a distinctive species-rich open shrub land. Croton socotranus and Jatropha unicostate are the two main abundant endemic shrubs present here. Other vegetation includes succulent trees, such as Euphorbia arbuscula, Dracaena socotranus, Adenium obesum spp. Socotranum, Boswellia spp., Sterculia africana var. socotrana, and Commiphora spp. [9]. On the slopes of the Haggier Mountains, there are areas of semi-deciduous vegetation dominated by Buxus hildebrandtii, Carphalea obovata, Rhus thyrsiflora, Cephalocroton socotranus, Allophylus rhoidiphyllus, Dragon Blood Tree (Dracaena cinnabari) and many limestone plateau areas landscaped by Desert Rose (Adenium obesum subsp. socotranum) (Figure 4).

\section{Socotra Archipelago Ecological Characteristics and Biodiversity}

The Socotra archipelago is unparalleled for its unique flora and marine and

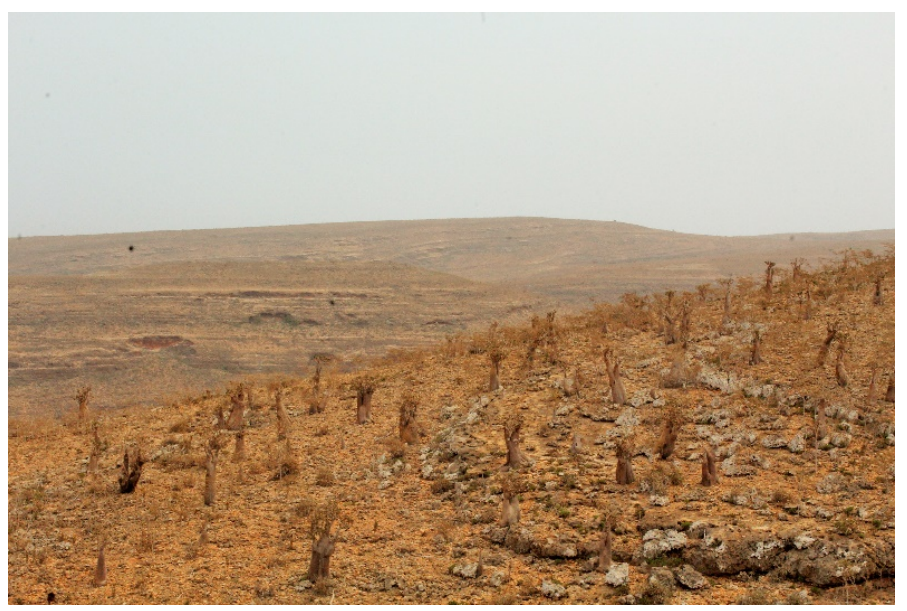

Figure 4. Plateau landscaped with desert rose (photo by author, Socotra 2018). 
terrestrial fauna and is considered a jewel of biodiversity and endemism in the Arabian Sea. Socotra is ranked as the world's tenth richest island for endemic plant species per square kilometer with $37 \%$ endemic species, which makes the ratio comparable with that of the Galapagos and higher than those found in Mauritius, Rodrigues, or the Canary Islands, to name a few [5]. The high level of endemism in the archipelago is in accordance with its estimated geological age and ecosystem.

\subsection{Socotra Archipelago Flora and Endangered Species}

Notably, there are about 900 plant species on the island, which include 307 species of endemic plants [10]. The endemic species Dragon Blood Tree (Dracaena cinnabari), Socotra Desert Rose (Adenium obesum subsp. Socotranum) and Socotra Cucumber Tree (Dendrosicyos socotrana) are unique to the archipelago and are not found elsewhere on Earth.

\subsubsection{Dragon Blood Tree (Dracaena cinnabari)}

The Dracaena woodland on Socotra Island is one of the oldest forest communities on Earth. They are all endemic and confined to small habitats. The plateau hosts the largest population of Dragon's blood trees. These trees are supposed to be remnant of the Miocene-Pliocene age xerophyllous and sclerophyllous $\mathrm{Te}$ thyan flora [11] and are almost extinct everywhere due to Pliocene climate changes. Dragon Blood tree is a monocotyledonous evergreen tree with a typical umbrella-shaped canopy due to a "dracoid" ramification of its branches which helps in capturing the moisture (Figure 5). The dragon blood tree is an evergreen tree that can live up to 650 years and often reaches height of 35 to 39 feet. The name Dragon comes from the red-colored sap or resin that the tree produces.

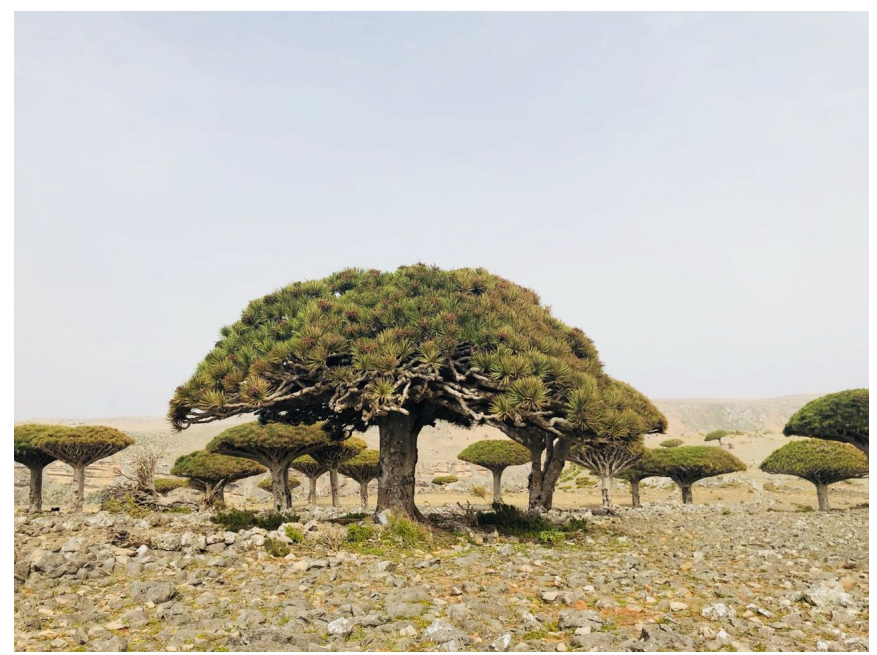

Figure 5. Dragon blood trees (Dracaena cinnabari) on barren plateau (photo by author, Socotra 2018). These trees are locally known as "Dam Al Akhawayn" (brother's blood tree). The local legends say that the Dragon's blood tree first grew on the spot where two brothers, Darsa and Samha, fought to the death. 


\subsubsection{Dragon's Blood}

Since antiquity, the island was famous for its Dragon's Blood, a red colored sap or resin produced by Dracaena cinnabari (Figure 6).

This red resin was believed to have magical and medicinal properties. It was frequently used as medicine for respiratory and gastro-intestinal problems in the Mediterranean basin and by early Greeks, Romans and Arabs. The resin was said to have strong antiseptic and immune-stimulating properties. Locals still use it for treating diarrhea, fevers, mouth ulcers; wound healing, skin diseases, for dye, varnish, cosmetic, incense, painting, decorating earthen pots and performing social rituals.

\subsubsection{Endangered Dragon Blood Tree (Dracaena cinnabari) and Other Endemic Species}

Dragon Blood Tree occurs in area with mean annual precipitation ranging from $207-569 \mathrm{~mm}$. The combination of climate change, habitat loss with insufficient regeneration of Dracaena growth, overgrazing by increasing population of livestock [12] [13], soil erosion, and increased aridity [12] and past cyclones are rendering the woodlands vulnerable to extinction [11]. The cattle overgrazing of the vegetation including Dragon tree seeds, predominantly by goats is also an important factor threatening the survival of the Dragon tree [5]. Consuming new sprouts of these trees from the seeds prevents Dracaena cinnabari and other species from thriving. Overgrazing also provokes soil erosion by causing loss of perennial vegetation layer and the thin organic top soil following monsoon rains. Both grazing and prolonged drought periods make it very difficult for the recovery of vegetation. The Dracaena seedlings have extremely low survival capacity in open habitats if not protected against goats and other livestock [12] [14]. Increasing aridity due to ongoing climatic change is likely to drastically reduce the potential habitat of the Dracaena cinnabari in the coming years. Another concerning factor is that most Dragon Blood Trees on Socotra Island are mature and subject to progressive decline. There seems to be little natural regeneration of the species. Measures must be put in place to change this situation by controlling overgrazing, growing seedlings in protected areas, preventing soil erosion and implementing other methods of conservation. In the absence of conservation actions, these species are likely to become extinct in near future.
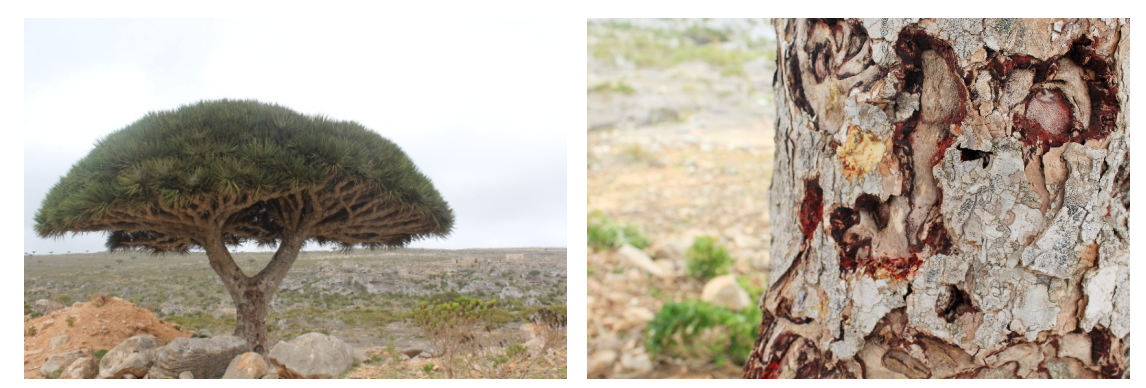

Figure 6. The dragon blood tree not only has a very distinctive appearance but also releases a red sap, or resin, known as “dragon's blood” (photo by author, Socotra 2018). 
There is also another unique endangered endemic species, the Desert Rose (Adenium obesum subsp. socotranum). This tree is also known as the "bottle tree" for its bottle-shaped trunk which looks swollen and bulbous in its stem to hold water on Socotra's desert plateau (Figure 7).

The tree produces a whitish irritating or poisonous latex containing many alkaloids which protects it from grazing animals (Figure 8).

Other endemic Socotra plants include the extremely rare Cucumber tree from Cucurbitacae family (Dendrosicyos socotranum), giant succulent tree (Dorstenia gigas), rare Socotran pomegranate Lythraceae from Loosestrife family (Punica protopunica), Socotran aloe (Aloe perryi), and Socotran Frankincense Tree (Boswellia socotrana).

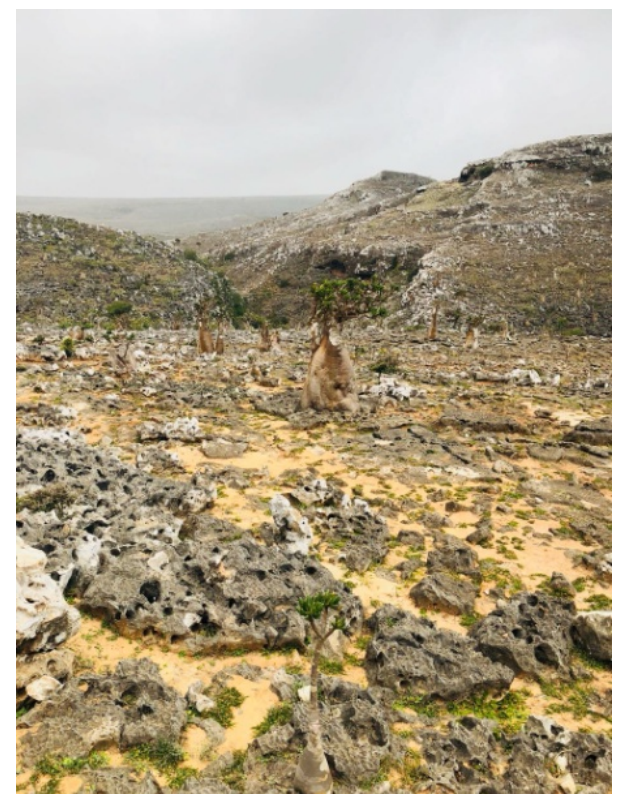

Figure 7. Desert rose "bottle tree" on barren plateau (photo by author, Socotra 2018). The tree survives the desert plateau by storing water in its trunk.

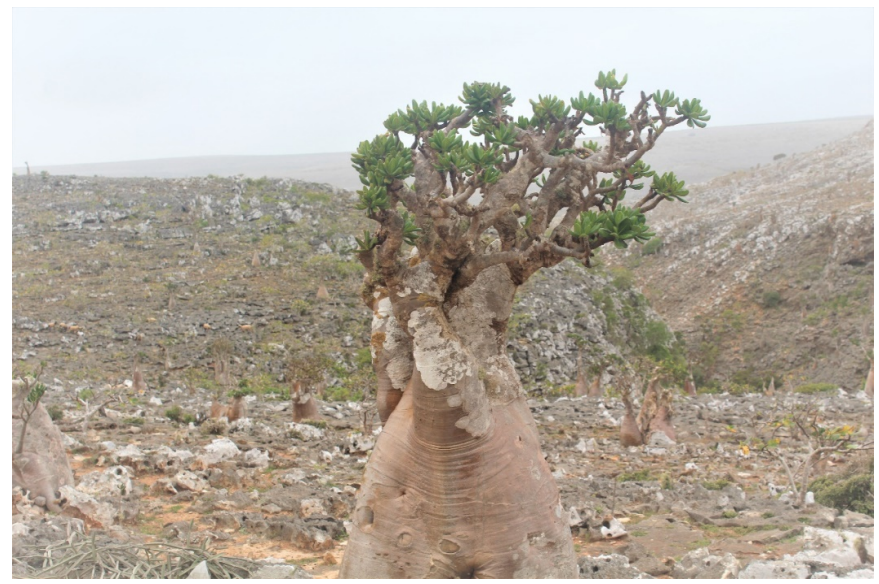

Figure 8. Desert rose "bottle tree" (Adenium obesum subsp. Socotranum) (photo by author, Socotra 2018). The desert rose has not yet suffered greatly from overgrazing, owing to its poisonous sap. 
Socotra has seven Boswellia species, all being endemic and is becoming increasingly rare because of overgrazing. The limestone plateau and the Haggier Mountains are considered the richest areas for endemic fauna, though the endemic species are scattered throughout the island in every type of vegetation. However, due to habitat fragmentation, climatic changes and degradation, several endemic plant species are now endangered.

\subsection{Socotra Archipelago Fauna and Endangered Species}

The island has a rich avifauna and is home to 180 species of birds with 10 endemic species including Socotra Cisticola (Cisticola haesitatus), Socotra warbler (Cisticola incanus), Socotra bunting (Emberiza socotrana), Socotra sunbird (Nectarinia balfouri), Socotra starling (Onychognathus frater), and Socotra sparrow (Passer insularis) [15]. Additionally, the island hosts 190 species of butterfly with high endemism. The insect fauna is also very rich with 600 species of insects with high incidence of endemism [10].

There are about 14 species of mammals, including wild and domesticated species, most of which are introduced from the outside world [10]. In the archipelago, at least 54 records of four bat species belonging to four families are known; viz. Rhinopoma cystops Thomas, Rhinolophus clivosus Cretzschmar, Asellia italosomalica De Beaux and Hypsugo lanzai Benda, Al-Jumaily, Reiter et Nasher.

The reptilian fauna is also very rich. There are numerous reptiles on the Archipelago, including the Socotran chameleon and several types of skinks, which are lizards that resemble snakes, but with very small limbs. Twenty-seven species of terrestrial isopods from Socotra Island have been recorded. An extremely high level of endemism is found in Socotra's reptiles (34 species, 90\% endemism) and terrestrial mollusks (land snails, 96 species, $95 \%$ endemism), isopods (73\%) and arachnids (60\%).

The archipelago's marine life is also very diverse with island supporting unique coastal fish assemblages of more than 800 species of fishes, 300 species of crab, lobster and shrimp and 253 coral-associated ("reef") species in spite of limited biogenic reef frameworks in the archipelago. The coral reefs of Socotra are diverse, and host many endemic species [16]. There are about 230 species of hard corals (of which five are endemics) and 30 species of soft corals. In addition it is home to 300 species of crustacean (out of which nine are endemics), 490 species of mollusks, 230 species of algae, 2 nesting species of sea turtle and many whale and dolphin species in vicinity. An endemic fresh-water crab, Potamon socotrensis, is common in the temporary water-courses [10]. Because of this exceptional marine diversity the Archipelago has been declared as "Ecologically or Biologically Significant Marine Area” (EBSA) in 2016 (Figure 9).

\section{Socotra Archipelago Endangered Ecosystem and Mounting Challenges}

The people of Socotra have lived in a synergistic balance with their environment 


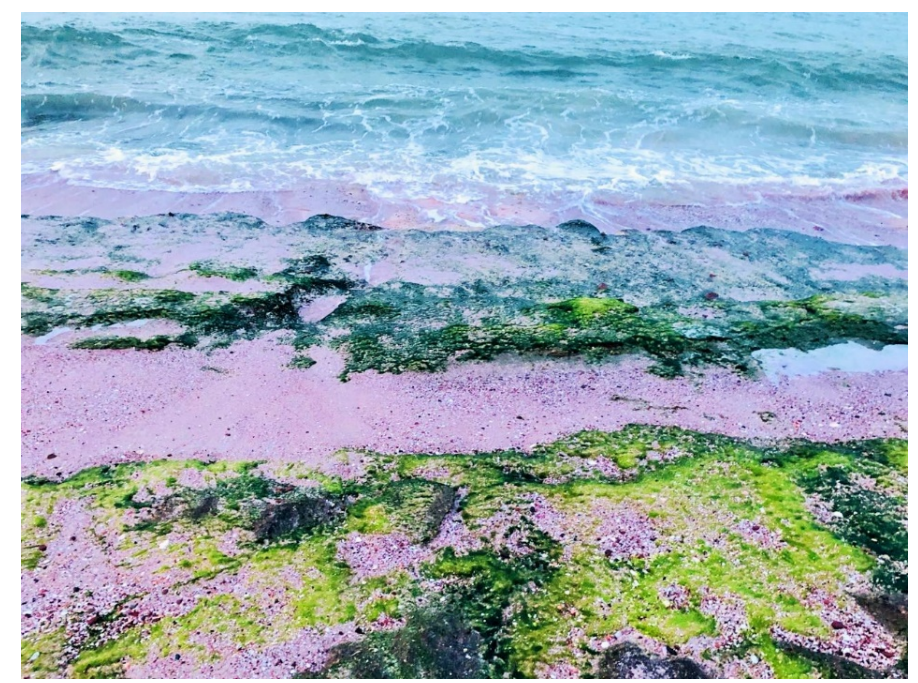

Figure 9. Ecologically or biologically significant marine area (EBSA) (photo by author, Socotra 2018).

for centuries. Poor access to the obscure island, with no safe harbor and long-term political instability in the region, has resulted in centuries of limited connection between Socotra and the rest of the world. For this reason, a fragile balance of sustainable co-existence of man and unique ecosystems remain maintained until recently. Now the Socotra ecology is now increasingly being affected by the degradation of vegetation, climatic changes, soil erosion, fragmentation and also by negative effect of coastal area acquisitions including marine resources use [17] [18].

Socotra inhabitants greatly rely on trees, whose wood is used for heating, cooking and as construction material for housing, roofing and fencing. As the availability of dead wood is no longer enough to meet growing demands, live trees is now being increasingly cut, thus posing a serious threat to the survival of endemic species. The wood is also burned for the manufacturing of lime, which is used in traditional buildings. In addition certain woody species such as the vulnerable Cephalocroton Socotranus are burned for their scented smoke by the inhabitants. The use of wood for all these purposes is causing a significant harmful effect on Socotra's terrestrial ecosystem. Additionally, the recent cyclones also caused destruction of innumerable mature trees including Dracaena cinnabari, Boswellia spp, Sterculia africana, Jatropha unicosta, Ziziphus spina-cristi and Croton socrotanus. The storms also eroded soil, uprooted many rare plants including the iconic dragon's blood tree, damaged coral reefs and caused substantial livestock losses.

Overharvesting of natural marine resources is also having a negative impact on Socotra's biodiversity due to inappropriate management, monitoring and enforcement of the law. The development of commercial overfishing over the island's traditional small-scale fisheries is also negatively affecting the marine ecosystem, and added threat is posed from the unauthorized commercial fishing, illegal hunting of sea turtles and collection of sea cucumbers, lobsters and shark 
fins. There are also reports of illegal export of coral stone causing further damage to the marine value of ecosystem.

Other major threats to the till-now preserved natural habitats of the Socotra Archipelago are the increase in tourism causing road and infrastructure development, increasing immigration and import of goods from mainland Yemen and other neighboring countries, and pollution by irreducible waste around settlements [19].

According to the report of World Heritage Centre and IUCN, the Outstanding Universal Value (OUV) of Socotra is significantly threatened by uncontrolled developments, unsustainable use of natural resources, continuous loss of forest substrate and the absence of adequate insecurity measures to avoid the risk of introduction of Invasive Alien Species (IAS). They report that multiple coastal and inland developments including building construction and new house constructions are partially taking place in violation of national protected areas and Conservation Zoning Plan of Socotra Islands (CZP), which endanger the longevity of Socotra. The recent road construction to the mountains is also having a negative environmental effect on the ecosystem. The land acquisition in coastal areas for recreational purposes, human settlements and roads for picturesque views present further serious threat to the associated marine and adjacent terrestrial ecosystems [17].

There is lack of sewage facilities and limited solid waste management systems on the island. The number of cars on the island is on the rise annually. The cars are usually second-hand imports from neighboring Middle East countries, and their emission levels are not controlled, further endangering the ecosystem (Figure 10).

There are no effective controls in place at airports or ports to control import of foreign flora and fauna species, and EPA has limited capacity to enforce such controls. Though there is a ban on removal or export of Socotra Flora and Fauna, there are many reported incidences of smuggling of rare plant species including endemic Dragon tree and Cucumber tree out of the Socotra Archipelago.

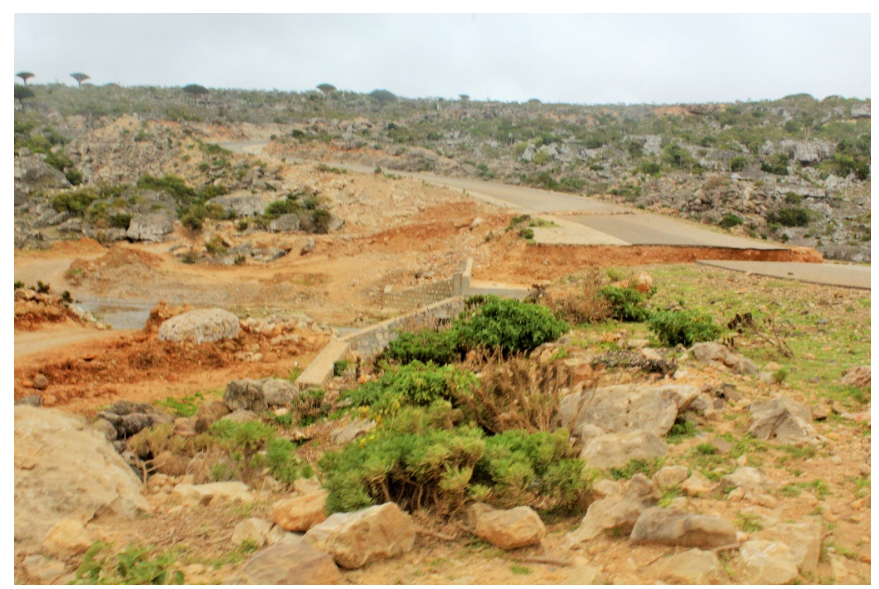

Figure 10. Road construction endangering ecosystem (photo by author, Socotra 2018). 
The local government has limited financial resources and limited protective forces, and thus the legal enforcement of local protective legislation is difficult to implement. The ongoing civil war and political instability of Yemen is also adversely affecting the environment and conservation efforts of preserving Socotra's ecosystems [20].

The ongoing COVID-19 pandemic has further limited the access to import of essential goods, leading to increased consumption of local resources further endangering the ecosystem.

\section{Current Status of Ecosystem and Biodiversity Preservation of Socotra Archipelago}

Considering the challenges faced by Socotra's fragile, closed ecosystem by human activities and climatic changes, the Socotra was declared to be the "Socotra Island Protected Area" under Yemeni Law in 1996. First key legislative management framework was adopted in 2000 for Socotra under Yemeni Presidential decree titled "the Conservation and Zoning Plan for the Socotra Islands."

To further preserve the biodiversity the Socotra Archipelago was declared UNESCO-Man and Biosphere Reserve in 2003 and UNESCO-Natural World natural Heritage Site (WHS) in July 2008. The WWF (World Wildlife Fund) listed Socotra in the Global 200 Eco-regions. Many projects like integrated conservation and development projects (ICDPs), Global Environment Fund (GEF) and UNEP later joined hands to protect the archipelago biodiversity and help in sustainable development and conservation of Socotra Archipelago. The Government of Yemen initiated the Socotra Archipelago Conservation and Development Program (SCDP) to sustainably conserve and develop the island of Socotra and its neighboring smaller island. This program was supported by the United Nations Development Programme (UNDP) and the Governments of the Netherlands, Italy and Poland in partnership with a pool of International Donors and NGOs. The main aim of the SCDP was to coordinate all government and donor efforts towards sustainable human development for the people of the Socotra Archipelago, while conserving the globally significant biodiversity of these unique islands. The European Union has supported such a move, calling on both UNESCO and International Organization of Protecting Environment to classify the island archipelago among the environmental heritages.

\section{Proposed Recommendations for Preservation of Socotra Archipelago Biodiversity}

To preserve the Socotra Archipelago unique biodiversity, implementation of long-term strategies envisaging a clear futuristic plan is required. We propose the following recommendations to preserve the Socotra Archipelago Biodiversity:

1) Protecting and propagating endangered species including Dragon blood tree by:

- Ecological restoration of native and endemic plant species by inhabitants in 
protected environment including local nurseries. This will help in ecological restoration of native plant communities, even if it takes many years for endemic trees to grow to maturity.

- Propagation of the endemic species with seeds and plants of endangered species from specialized local nurseries.

- Protecting aging Dragon blood trees from natural calamities.

- Protecting existing tree from being used as wood for fire and domestic use like house construction.

- Protecting the existing trees from human onslaught from unplanned infrastructural development including construction of roads to mountain.

2) Preserving habitat fragmentation and woodland degradation from overgrazing by feral and domesticated goats and other cattle.

3) Protecting and insulating the native ecosystem from invasive alien species (IAS) by biodiversity monitoring system, with emphasis on an early warning system with appropriate checks for invasive alien species.

4) Strengthening of the Sea port and Airport biological monitoring to avoid smuggling out of endangered species and introduction of invasive alien species in native ecosystem.

5) Establishing Marine Protected Areas (MPAs) to avoid marine resource exploitation with negative repercussions on marine wildlife.

6) Taking proactive steps for curbing soil erosion, increasing ecosystem resilience and addressing threats from unsustainable resources to terrestrial and marine ecosystems.

7) Revitalizing traditional resource management practices including pastoralism, fisheries and training of locals and Bedouin tribes for sustainable beekeeping for honey with understanding of potential economic benefits.

8) Strict enforcement of the Socotra archipelago's protected area regulations and developing buffer zones in complementary manner in Conservation Zoning Plan (CZP).

9) Enactment of local legislative laws and governance including Environmental Impact Assessment (EIA) and project approval prior to further infra-structural development and road construction.

10) Strengthening cross-sectoral management frameworks, improving knowledge and technical know-how with proper data compilation, processing and management.

11) Formulating a master plan for sustainable infrastructural developmental activities with controlled sustainable development plan for preserving the island's ecosystems and biodiversity. The financial investments must actively consider interest of the indigenous population.

12) Increasing environmental awareness in local population and strengthening local conservation efforts by employing adequate manpower.

13) Encouraging community-based sustainable eco-tourism for revenue generation with emphasis on preservation of endemic ecosystem with active participation and employment of local communities. 
14) Strengthening of the Sea port and Airport biological monitoring to avoid smuggling out of endangered species and introduction of invasive alien species in native ecosystem.

15) Preserving the cultural richness, folklore, Socotri language, and living in harmony with the nature should remain an integrated part of the archipelago's planning and management systems to preserve this island of heritage for future generations.

16) Educating and empowering the local population about the heritage status of the Archipelago and to co-manage the natural resources to protect their unique eco-cultural heritage.

17) Strengthening the local legislative laws for conservation which should be aided by a strong political will to protect, preserve and promulgate the Archipelago's unique bio-cultural diversity.

18) Lastly, a sustainable financial strategy needs to be formulated to ensure long-term preservation of this endangered ecosystem.

\section{Conclusions}

Socotra holds global importance for its exceptional level of biodiversity and endemism in many terrestrial and marine organisms. Conservation of this endemic ecosystem is not only important for preserving the diversity of ecological niches, but also preservation of an ancient culture. The imminent dangers to the until now well-preserved natural habitats of the Socotra Archipelago are plentiful including woodland fragmentation, overgrazing, commercial collection of wood, unsustainable fisheries, introduction of invasive alien species, smuggling out of endangered species, climatic changes threat, increasing pollution by waste around settlements, uncontrolled infrastructure development including roads to the mountains, increase in tourism, nonsustainable developments, lack of financial resources and non-diligent enforcement of international and national policies for bio-cultural preservation.

The strategic, result-oriented biodiversity preservation approach along with consideration of the proposed recommendations will not only help in protecting the Socotra's unique biodiversity from present and future challenges, but will also serve as a benchmark for biodiversity conservation around the globe.

\section{Conflicts of Interest}

The author declares no conflicts of interest regarding the publication of this paper.

\section{References}

[1] Del-Arco, M., Pérez-De-Paz, P.L., Acebes, J.R., González-Mancebo, J.M., Reyes-Betancort, J.A., Bermejo, J.A., De-Armas, S. and González, R. (2006) Bioclimatology and Climatophilous Vegetation of Tenerife (Canary Islands). Annales Botanici Fennici, 43, 167-192. https://doi.org/10.5735/085.046.0301

[2] Fernández-Palacios, J.M., De Nascimento, L., Otto, R., Delgado, J.D., García-Del-Rey, 
E., Arévalo, J.R. and Whittaker, R.J. (2011) A Reconstruction of Palaeo-Macaronesia, with Particular Reference to the Long-Term Biogeography of the Atlantic Island Laurel Forests. Journal of Biogeography, 38, 226-246. https://doi.org/10.1111/j.1365-2699.2010.02427.x

[3] Witt, C.C. and Maliakal-Witt, S. (2007) Why Are Diversity and Endemism Linked on Islands? Ecography, 30, 331-333. https://doi.org/10.1111/j.0906-7590.2007.04837.x

[4] Popov, G.B. (1957) The Vegetation of Socotra. Journal of the Linnean Society, 55, 706-720. https://doi.org/10.1111/j.1095-8339.1957.tb00031.x

[5] Miller, A.G. and Morris, M. (2004) Ethnoflora of the Socotra Archipelago. Royal Botanic Garden, Edinburgh, 759 p.

[6] Knapp, R. (1968) Höhere Vegetationseinheiten von “Athiopien, Somalia, Natal, Transvaal, Kapland und einigen Nachbargebieten. Geobotanische Mitteilungen, 56, $1-36$.

[7] Král, K. and Pavliš, J. (2006) The First Detailed Land-Cover Map of Socotra Island by Landsat/ETM+ Data. International Journal of Remote Sensing, 27, 3239-3250. https://doi.org/10.1080/01431160600646557

[8] De Sanctis, M., Adeeb, A., Farcomeni, A., Patriarca, C., Saed, A. and Attorre, F. (2013) Classification and Distribution Patterns of Plant Communities on Socotra Island, Yemen. Applied Vegetation Science, 16, 148-165.

https://doi.org/10.1111/j.1654-109X.2012.01212.x

[9] Davis, S.D., Heywood, V.H. and Hamilton, A.C. (1994) Centres of Plant Diversity. Vol 1: Europe, Africa, Southwest Asia and the Middle East. World Wide Fund for Nature and International Union for Conservation of Nature, Oxford, 354 p.

[10] Environment Protection Authority, Republic of Yemen (n.d.) Yemen Socotra Archipelago.

http://www.unesco.org/new/fileadmin/MULTIMEDIA/HQ/SC/pdf/sc_mab_Yemen SocotraArchipelago_EN.pdf

[11] Adolt, R. and Palvis, J. (2004) Age Structure and Growth of Dracaena cinnabari populations on Socotra. Trees, 18, 43-53. https://doi.org/10.1007/s00468-003-0279-6

[12] Attorre, F., Francesconi, F., Taleb, N., Scholte, P., Saeed, A., Alfo, M. and Bruno, F. (2007) Will Dragon Blood Survive the Next Period of Climate Change? Current and Future Potential Distribution of Dracaena cinnabari (Socotra, Yemen). Biological Conservation, 138, 430-439. https://doi.org/10.1016/j.biocon.2007.05.009

[13] Scholte, P. and De Geest, P. (2010) The Climate of Socotra Island (Yemen): A First-Time Assessment of the Timing of the Monsoon Wind Reversal and Its Influence on Precipitation and Vegetation Patterns'. Journal of Arid Environments, 74, 1507-1515. https://doi.org/10.1016/j.jaridenv.2010.05.017

[14] Habrova, H., Cermak, Z. and Pavlis, J. (2009) Dragon's Blood Tree-Threatened by Overmaturity, Not by Extinction: Dynamics of a Dracaena cinnabari Woodland in the Mountains of Soqotra. Biological Conservation, 142, 772-778. https://doi.org/10.1016/j.biocon.2008.12.022

[15] Stattersfield, A.J., Crosby, M.J., Long, A.J. and Wege, D.C. (1998) Endemic Bird Areas of the World. Priorities for Biodiversity Conservation. Birdlife Conservation Series No. 7, Birdlife International, Cambridge, 846 p.

[16] Cheung, C., DeVantier, L. and Damme, K.V. (2006) Socotra-A Natural History of the Islands and Their People. In: K. Van Damme, Ed., Odyssey Books and Guides, Air photo International Ltd., Hong Kong, 408 p. 
[17] Abulhawa, T. and Abdulhalim, H. (2013) Report on the Mission to Socotra Archipelago, Republic of Yemen from 4 to 14 November, 2012. UNESCO World Heritage Centre and IUCN.

[18] Abulhawa, T., Abdulhalim, H., Osipova, E. and Cummings, T. (2015) TABE'A II Report: Enhancing Regional Capacities for World Heritage. International Union for Conservation of Nature, Manama, ii+74 p. https://doi.org/10.2305/IUCN.CH.2015.04.en

[19] Van Damme, K. and Banfield, L. (2011) Past and Present Human Impacts on the Biodiversity of Socotra Island (Yemen): Implications for Future Conservation. Zoology in the Middle East, 54, 31-88.

https://doi.org/10.1080/09397140.2011.10648899

[20] Zajonz, U., Lavergne, E., Klaus, R., Krupp, F., Aideed, M.S. and Saeed, F.N. (2016) The Coastal Fishes and Fisheries of the Socotra Archipelago, Yemen. Coral Reefs of Arabia. Marine Pollution Bulletin, 105, 660-675.

https://doi.org/10.1016/j.marpolbul.2015.11.025 